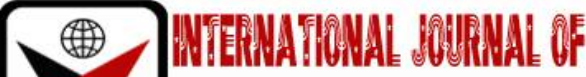 בmRक
}

ISSN 2278-0211 (Online)

\section{The Effect of Audit Firm Tenure on Audit Quality in Botswana}

\author{
Sihlobo Nyoni \\ Accounting and Finance Lecturer, Department of Accounting and Finance, \\ Ba Isago University, Botswana \\ CollenTichaonaMahambo \\ Accounting and Finance Lecturer, Department of Accounting and Finance, \\ Ba Isago University, Botswana
}

\begin{abstract}
:
The primary objective of this research is to check hoe tenure of auditor is affecting the audit quality. It also tries to establish whether mandatory audit firm rotation need to be started in Botswana or not. The study was descriptive in nature and a sample of 3 Accounting Firms and 12 Accountants from companies was drawn from the list of accredited auditors and listed companies on the Botswana Stock exchange. Data collected was analysed using statistical analyses software package, SPSS version 21 in order to determine the audit quality level in relation to audit tenure. Audit quality was determined from the analysis of different factors affecting audit report quality, frequency tables where used to analyse the responses of the sample population. The findings proved that a prolonged Audit tenure results in impaired audit quality. It was recommended that there is need to develop alternative measures to safeguard auditor's quality.
\end{abstract}

Keywords: Audit, audit firm tenure, audit quality

\section{Background of the Study}

Investors continue to loose their investment due to weak form of market effeciency in providing investment information. The Audit function cannot be spared as a key involved party. The primary concerned areaa is the internal control weaknesses, disagreements on accoounting, inability to rely on management, scope limitation, unauthorised opinion, and illegal acts. The refelection of theses types of deficiences seen on company's accounting and Audit system which in the long run hampered the reported financial results. Independence impared and cost reduction reasons could have implications for the audit hence the need for change of auditor arises.

As a way of mitigting such challenges, mandatory audit firm rotation has been welcomed by the Botswana Accountancy Oversight Authority (BAOA) with effective from $1^{\text {st }}$ January 2019 (BAOA, 2019). BAOA went on to agree on terms of MAFR after considering and consulting with its local stakeholders who are mainly the Public Interest Entities (PIEs), its regional peers in South Africa and Mauritius, and eventually, internationally with its European Union and United Kingdom counterparts who all have already adopted MAFR. The shortage of accounting and auditing skills in Botswana ahd been highlighted by the MAFR adoption, BAOA (2019). They recommended that there should be no rotation of senior audit staff other than the Engagement Quality Control Review (EQCR), and the lead partner.

Proponents of mandatory audit firm rotation argue that long-tenure relationships between audit firms and clients can lead to audit failures due to high levels of familiarity that impair auditors' independence and professional skepticism (Moore et al. 2006, Gavious, 2007).

Opponents of mandatory audit fim rotation argue that long tenure auditor-client relationships lead to valuable client and industry specific knowledge over time resulting in enhanced audit quality. Short tenure may be problematic as audit firms try to build relationships with their clients, and mandatory rotation likely would be a hinderance to such a relationship (PCAOB 2011b, 2011c). A lack of familiarity may have adverse consequences, which could be exacerbated by insituting mandatory audit firm rotation (Roush et al, 2011). The primary purpose of this study is to investgate Botswana corporate community's perspective on the issue of the recent changes in the Auditor tenure and how it impacts on auditor independence and financial reporting quality. The researcher endeavors to improve the understanding of the underlying reasons behind the positions of audit committee members on mandatory audit firm rotation. The study also examines how audit committee members currently ensure auditor independence and objectivity and how audit committee chairs maintain and monitor a series of important relationships including the audit committee-external auditor relationship, the audit committee-financial management relationship, and the external auditor-financial management relationship. Finally the study explores audit committee members' views on the costs associated with switching audit firms 


\section{Literature Review}

\section{1. Auditor Tenure}

The length of relationship between auditor-client is known as auditor tenure. A threat to independence can be noticed due to too long association between the auditor and his client. As a result less attentiveness can be noticed from auditors end. According to Watts and Zimerman (2006), more association between client and auditor hampers the quality checking which results in weaknesses of internal control and risk sources. Geiger and Raghunandan (2002), presented a different view by mentioening that the audit quality is relatively lower in the initial years of an auditor-client relationship, specifically, short tenure is positively associated with audit reporting failures. Concerns had bene rasided by Enron, WorldCom and Global Crossing regarding the role of the auditor. According to Chi (2010) and IFAC (2003), lack of audit independence creates decreased credibility for the financial information.

Arel et al (2005), also expressed concern regarding the lack of auditor independence. Other important organizations like IFAC and GAO have focused on mandatory audit firm rotation. Lack of proper auditing and quality checking can easily result in acceptance of destructive accounting and failure in detecting frauds (Myers et al, 2003). Many scholars had argued for mandatory audit firm rotation as it increases the auditor's independence, objectivity and create a fresh new viewpoint of the financial statements. Whereas, the opponents argue that it tends to increase costs for the companies' and lost knowledge about the business. As per Geiger and Raghunandan (2002), more common audit failure had been seen in the early years when the auditor is not familiar with the company.

\subsection{Audit Quality}

Audit quality refers to the degree of cahnces with which an auditor determines and straightforwardly hearsays the rupture, mistatement, material errors and ommissions in client's accounting system (DeAnggelo in Taqi, 2013). According to Adeniyi and Mieseigha (2013), Audit report quality helps to enhance the authority of financial statements. Another study found an inverse relationship between auditor tenure and audit quality (Barbadillo \& Aguilar, 2008). They also highlighted that auditors tend to be more reliant on in the initial years of the auditing engagement. As per Ebimobowei and Oyadonghan (2011), mandatory rotation of auditors creates a positive effect on quality of audit reports. Another research conducted by Adeyemi and Okpala (2011), found that audit firm's tenure can result in a loss of auditor's independence. Many researches had been done to the check the effect of long association of auditors with clients. Whether this is affecting the audit quality or not. This study aims to find the effect of audit firm tenure on auditor reporting quality in Botswana audit setting.

\section{Research Methodology}

Here, descriptive research design has been adopted. The study was qualitative and therefore a survey research method was used by the researchers. The survey method allows the collection of a large amount of data from a sizeable population in a highly economical way (McNeill, 2005). This research design helps to examine and explain the effect of audit firm tenure on auditor independence. The target population for this study comprises listed companies and audit firms. The research requires sound understanding of auditing, financial reporting and corporate governance on the part of the respondents, hence stratified random sampling was deemed suitable on the selection of the research subjects. The sample size for the research was adapted from Saunders et al (2005). The sample size of 3 Audit Firms and 12professional accountants out of 33 of the listed companies on the Botswana Stock Exchange was used. Data was collected through the use of structured questionnaires, in depth interviews with key personnel from the sampled companies and audit firms. The researchers used Statistical Package for Social Sciences (SPSS version 21.0) software to analyze the data obtained from the questionnaire. The data was presented inform of tables for easy understanding.

\section{Findings and Analysis}

The data was analysed in the context of secondary data which is data and facts that already exist and primary data was collected using questionaires. The data was organized and presented using frequency tables.

\begin{tabular}{|c|c|c|c|c|c|}
\hline \multicolumn{1}{|c|}{ Valid } & Frequency & Percent & Valid Percent & Cumulative Percent \\
\cline { 2 - 5 } & Tenure of engagement & 11 & 73.3 & 73.3 & 73.3 \\
& Tenure of the audit Partner & 3 & 20.0 & 20.0 & 93.3 \\
\cline { 2 - 5 } & Number of clients/auditor & 1 & 6.7 & 6.7 & 100.0 \\
\cline { 2 - 5 } & Total & 15 & 100.0 & 100.0 & \\
\hline
\end{tabular}

Table 1: Factors That Affect Quality Most

Table 1 shows factors affecting audit quality, on the tabled factors that affect audit firm quality, (73.3\%) were in opinion that the tenure the auditor engages on one client has a significant influence on the quality of work performed on the client. $20.0 \%$ of the idea that it is the tenure of the audit partner not the audit firm that matters most while $6.7 \%$ subscribed to the notion that the number of clients that the auditor has determines the level of quality that the auditor exercises towards the client. 


\begin{tabular}{|c|c|c|c|c|c|}
\hline \multicolumn{2}{|c|}{} & Frequency & Percent & Valid Percent & Cumulative Percent \\
\hline \multirow{3}{*}{ Valid } & $0-3$ & 2 & 13.3 & 13.3 & 13.3 \\
& $3-5$ & 8 & 53.3 & 53.3 & 66.6 \\
\cline { 2 - 5 } & $5-10$ & 5 & 33.4 & 33.4 & 100.0 \\
\cline { 2 - 5 } & Total & 15 & 100.0 & 100.0 & \\
\hline
\end{tabular}

Table 2: Number of Years Served by Current Auditor

Table 2 shows results on the number of years that the companies had retained the current auditor, $53.3 \%$ of the sample had retained the current auditor for a period of 3 to 5 years while $33.3 \%$ had retained the current auditor for a period of $5-10$ this shows that $86.7 \%$ of the sampled companies have retained the same auditor for longer periods of time.

\begin{tabular}{|c|c|c|c|c|c|}
\hline \multicolumn{2}{|c|}{} & Frequency & Percent & Valid Percent & Cumulative Percent \\
\hline Valid & After audit failure & 9 & 60.0 & 60.0 & 60.0 \\
& When it becomes uneconomic & 4 & 26.7 & 26.7 & 86.7 \\
\cline { 2 - 6 } & When the Auditor become too & 2 & 13.3 & 13.3 & 100.0 \\
\cline { 2 - 6 } & familiar with client & & & & \\
\hline
\end{tabular}

Table 3: Reasons Why Companies Change Auditor

Table 3 shows results of the respondents agreeing to the hypothesis of changing auditors. Of the 15 respondents; $60 \%$ cited audit failure as the reason for change while other $26.7 \%$ cited economic factors and only $13.3 \%$ citing familiarity as reason for change of auditor as tabulated on the table above. Participants indicated that the most significant cost associated with changing auditors is the time and effort involved in the tendering process and in bringing a new auditor up to speed with client- and industry-specific knowledge.

Respondents were also asked if there were any cases of audit failures in their firms, $60 \%$ of the respondents said their companies once experienced Audit failures, of the $60 \%, 20 \%$ cited disagreement as the cause of failure while $40 \%$ cited limitation of scope as the cause of failure.

All the respondents were of the idea that the tenure of the auditor should be limited and 66.7\% supporting fiveyear tenure while three $7.1 \%$ segments of the respondents picked 4; 6 and 8 years respectively as the ideal tenure for auditors to engage with a single client. $12 \%$ think 10 -year tenure can be the best to strike a balance between the effects of the learning curve and diminishing returns.

\section{Discussion}

The study results show that most companies on the BSE are maintaining the same auditors for longer periods beyond five years, the reasons given by respondents on the reasons for retaining auditors are: i.A great percentage of auditor changes are due to audit fees and to refresh the perspective of investors concerning the issue of quality. This in accordance with literature which stated that auditor changes occur more frequently following receipt of a qualified opinion so as to try to improve their company's image to the outside world.

The other reason was the desire to reduce audit fees so as to improve company performance by reducing company expenditures.

Another major finding was that most companies did not have standing policies that governed the tenure of service of their audit committees. The effect of the auditor's tenure with one client is two-fold, firstly a very short tenure compromises audit quality due to auditor's lack of client's industry specific knowledge, while a very long tenure poses a threat to auditor independence due to relationships built with the client overtime that impair objectivity. Moreover, familiarity may pose a threat on the thoroughness of the audit work performed.

\section{Conclusion and Recommendations}

The study concluded that a prolonged tenure for the audit firm results in impaired audit quality due to continuous interaction of the auditor with the company's management. The study also concluded that limiting auditor tenure rejuvenates investors' confidence in the companies' audit system through enhancing audit firm quality.

In light with the above conclusions, the researchers recommend that Auditor tenure should be restricted to a period of at most 5 years with lead audit partner rotated in a period of not more than 3 years. This can strike the balance between auditor's time to get industry specific knowledge of client and the same time eliminating complacence on the part of the auditor.

The audit firm should be allowed to compete again for audit services after a period of not less than 5 years which is technically after the tenure chair of the audit committee who is presumed to be an independent non-executive director according to the recommendation by the several codes of corporate governance such as king 111, Sarbanes Oxley, and the OECD codes. The study did not include public interest enterprises such as medical aids, pension funds and insurance companies, the researchers recommend future studies to be carried out on these enterprises. Future research can also be done to empirically explore the added value for the audit client resulting from a long relationship with the auditor by examining the synergies that can develop between the audit committee, management and audit firm. 


\section{References}

i. Adeniyi, S. I., \&Mieseigha, E. G. (2013). Audit tenure: An assessment of its effects on audit quality in Nigeria. International Journal of Academic Research in Accounting, Finance and Management Sciences, 3(3), $275-283$.

ii. Adeyemi, S. B., Okpala, O., \&Dabor, E. L. (2012). Factors affecting audit quality in Nigeria. International Journal of Business and Social Science, 3(20).

iii. Arel et al, (2005)) Auditing Principles: A system-based approach, 5th edition, eaglewood cliffs, New Jersey, Prentice Hall

iv. Bedard, J.Coulombe, D. and Courteau L. (2004) Audit Committee Effectiveness, Audit Quality and Earnings Management,

v. Chi, (2010); The use of audit committee for monitoring Journal of Accounting and public policy vol13 pp121-139

vi. Deangelo, (2001) Empirical analysis of the economic demand for auditing in the initial public offering market Journal of Accounting Research vol37 225-238

vii. Ebimobowei, A., \&Keretu, O. J. (2011). Mandatory rotation of auditors on audit quality, costs and independence in SouthSouth, Nigeria. International business management, 5(3), 166-172.

viii. $\quad$ Fan P.H. and Wong T.J. (2005) Ownership Structure, Agency Problems, and Auditor Choice

ix. Frankel, R.M., Johnson, M.F. and Nelson, K. K, (2002) The Relation Between Auditors' Fees for Non-Audit Services and Earnings Management MIT Sloan, Working Paper No. 4330-02

x. Gavious, I. (2007). Alternative perspectives to deal with auditors' agency problem. Critical Perspectives on Accounting, 18(4), 451-467.

xi. Geiger M. A. and Raghunandan, K (2002) Auditor Tenure and Audit Reporting Failures Auditing: A Journal of Practice \& Theory, Vol. 21, No. 1, March 2002

xii. IFAC. (2003) Quality levels of predecessors and successor auditor evidence from the reasons reported by managers for changing auditors Working paper Business Finance pg. 243-261

xiii. Jensen, M. and Meckling,W. (2010)Theory of the Firm Harvard Business School Harvard University Press

xiv. Knapp (2001),The relationship between going concern, opinion and auditor loss function Journal of Accounting research vol 36 pg. 143-156

xv. Majinda, D. (2019). Mandatory Audit Firm Rotation Guidance on Recommended Best Practice | BAOA-Botswana Accountancy Oversight Authority. Retrieved 10 December 2019

xvi. McMullen (2006) Auditing today, 5th edition Cincinnati South Western College Publishing.

xvii. $\quad$ McNeill, P., \& Chapman, S. (2005). Research methods. Psychology Press.

xviii. $\quad$ Michael Spence in (1973) Job Market SignallingThe Quarterly Journal of Economics, Vol. 87, No. 3 (Aug., 1973), pp. 355374. Published by: The MIT

xix. Moore, D. A., Tetlock, P. E., Tanlu, L., \&Bazerman, M. H. (2006). Conflicts of interest and the case of auditor independence: Moral seduction and strategic issue cycling. Academy of Management Review, 31(1), 10-29.

xx. Morris, R. D. (1987). Signalling, agency theory and accounting policy choice. Accounting and business Research, 18(69), 47-56.

xxi. Mugenda (2003) Mugenda, O. M. \&Mugenda, A. G. (2003). Research methods: Quantitative and qualitative Approaches. Nairobi: African Centre for Technology Studies.

xxii. Mushier (2003) Auditing: Theory and Practice, 2nd edition, Essex Pearson Education.

xxiii. $\quad$ Myers et al (2003). Fundamentals of Practical auditing, 6th edition, Eastern Economy, New Delhi, India.

xxiv. O'Reilly and Caldwell (2001 Culture and Demography in Organizations Stanford Graduate School of Business

xxv. Pigé, 2000 Auditor independence dismissal threats and the market reaction to Auditor switch Journal of accounting research vol 30 pg. 1-23

xxvi. Public Company Accounting Oversight Board (PCAOB). (2011). Concept release on auditor independence and audit firm rotation. PCAOB Release No. 2011-006.

xxvii. Quinones (2005) Does opinion shopping impair Audit quality, auditor independence Journal of Accounting research vol 44 pg. 561-583

xxviii. Roush, P. B., Church, B. K., Jenkins, J. G., McCracken, S. A., \& Stanley, J. D. (2011). Auditor rotation: The PCAOB considers a new direction. Current Issues in Auditing, 5(2), C15-C20.

xxix. Salancik, (2007); O'Reilly and Caldwell, 2001Saunders et al., 2003 Research Methods for Business Students Prentice Hall

xxx. Saunders, M. N. (2011). Research methods for business students, 5/e. Pearson Education India.

xxxi. Schmidt et al (2006) The use of audit committee for monitoring Journal of Accounting and public policy vol13 pp121139

xxxii. Stefaniak, C., \& Robertson, J. C. (2010). When auditors err: How mistake significance and superiors' historical reactions influence auditors' likelihood to admit a mistake. International Journal of Auditing, 14(1), 41-55.

xxxiii. Stiglitz (2002) Signalling Theory: A Review and Assessment

xxxiv. Sweeney, (2004) Empirical analysis of the economic demand for auditing in the initial public offering market Journal of Accounting Research vol37 225-238

xxxv. Taqi, M. (2014). Consequences of audit quality in signalling theory perspective. GSTF Journal on Business Review $(G B R), 2(4)$.

xxxvi. Tepalagul, N., \& Lin, L. (2015). Auditor independence and audit quality: A literature review. Journal of Accounting, Auditing \& Finance, 30(1), 101-121.

xxxvii. Watts \& Zimmerman, (2006). Do Spanish firms change auditors to avoid a qualified opinion International Journal of Auditing vol7 pg3 